\title{
Service Life Prediction and Management of Concrete Bridge Structures Due to Corrosion
}

\author{
Moe M. S. Cheung ${ }^{1}$ and Kevin K. L. So ${ }^{2}$ \\ 1. Western China Earthquake and Hazards Mitigation Research Centre, Sichuan University, Chengdu 610000, China \\ 2. Faculty of Science and Technology, Technological and Higher Education Institute of Hong Kong, Tsing Yi, Hong Kong, China
}

\begin{abstract}
The increasing stocks of public infrastructure and serious deterioration of infrastructure systems due to corrosion present great financial, safety, technical and operational challenges to government organizations in charge of public infrastructure development and management. To meet those challenges, a performance-based life-cycle management model for reinforced concrete structures was proposed in this paper. This model predicts the life-cycle performance of infrastructure based on the corrosion-induced deterioration mechanism: condition index as well as performance limit states. A case study is provided to demonstrate the use of the proposed performance-based life-cycle cost management model.
\end{abstract}

Key words: Concrete structure, corrosion, deterioration, life-cycle management.

\section{Introduction}

Reinforced concrete is widely used in modern infrastructure development. The combination of concrete and steel reinforcement significantly improves the mechanical performance and durability of concrete structures. The encasement of reinforcement in concrete provides the reinforcement with a protective environment that reduces reinforcement corrosion and allows it to function effectively as reinforcement. However, the reinforcement in concrete still corrodes and this is a commonly encountered cause of deterioration in many concrete structures. The serious deterioration of infrastructure systems presents great financial, safety, technical and operational challenges to government organizations in charge of public infrastructure development and management.

Currently, there are a significant amount of researches carried out in the area of corrosion initiation and corrosion propagation of reinforced

Corresponding author: Kevin K. L. So, assistant professor, research fields: life-cycle management, asset management, project finance and infrastructure development. E-mail: kklso@ouhk.edu.hk. concrete structures. However, it lacks of information on the mapping of these pertinent corrosion mechanisms to the field conditions and performance limit states. This is a very important linkage which we must develop in order to use them to develop life-cycle management strategies for reinforced concrete infrastructures.

This paper closed the above knowledge gaps and has developed a performance-based life-cycle management model for reinforced concrete structures. This model is characterized by the following aspects: (1) The corrosion-induced deterioration mechanism is used to predict the service life of concrete structures; (2) The performance of concrete structures is measured by the condition index; (3) The performance limit states are mapped with condition index and field inspection data to come up with maintenance and renovation strategies. A case study is provided to demonstrate the use of the proposed performance-based life-cycle management model.

\section{Corrosion Induced Problems in Reinforced Concrete Structures}

The alkaline condition of concrete leads to the 
formation of a protective thin film on the surface of the reinforcement. The protective thin film is dense and impenetrable, which prevents further corrosion of the reinforcement if fully developed and maintained. However, if the alkalinity condition is reduced by the penetration of acidic gases such as carbon dioxide, or if chloride ions are present at the reinforcement surface, the protective thin film may be destroyed, leading to corrosion of the reinforcement. Rust, the products of corrosion, will absorb water and increase its volume. The forces generated by this expansive process can far exceed the tensile strength of the concrete, resulting in cracking and spalling of the concrete cover. Consequently, the corrosion induced cracks allow more moisture, carbon dioxide and/or chloride getting into concrete easily, accelerating the corrosion rate of reinforcement.

Corrosion of steel reinforcement causes structure distress because of the loss of both concrete and reinforcement section areas and the consequent loss of load capacity [1]. Corrosion damage is often in structures where humidity is more readily maintained and at the base of the bridge column in contact with the soil where there is a greater tendency to accumulate salts due to capillary action. Corrosion leads to damage through delamination, concrete spalling, and exposure of reinforcement. This further reduces the cross-section of reinforcement which may become a safety hazard. Such damages can be quite critical for bridges located at coastal areas and marine structures.

\section{Steel Reinforcement Corrosion Mechanism}

\subsection{Carbonation}

The carbonation of concrete is a consequence of chemical reactions of the alkaline components of the cement paste with the atmospheric carbon dioxide. These reactions can only occur in the presence of a certain amount of water. Carbon dioxide reacts with the hydroxides to form carbonates and water. This reaction reduces the $\mathrm{pH}$ value and reinforcement will corrode in an environment where $\mathrm{pH}$ is lower than 8 . The penetration rate of the carbonated front into the hardened concrete depends on the partial pressure of carbon dioxide, concrete permeability, cement type, and cement content. Increasing concrete cover depth over reinforcement, increasing density of the concrete and using higher amounts of cement in the concrete will reduce the incidence of carbonation caused damage.

\subsection{Chloride Attack}

Chloride ions from deicing salt or from sea spray in marine environments can penetrate through the concrete cover to reach the embedded reinforcing steel. Chloride ions also can be mixed with concrete inadvertently as part of the water or aggregate. In some cases, chloride ion is present in admixtures such as calcium chloride, which is a set-accelerator to reduce the setting time in concrete construction. The alkaline passive condition in concrete will be disrupted and the reinforcing steel corrosion will start to occur when the amount of chloride ions reaches the critical content at embedded reinforcing steel surface.

\subsubsection{Anode Area-Oxidation Process}

Reinforcement corrodes at the anode area. The chemical reaction is the same whether corrosion occurs by chloride attack or carbonation. When reinforcement in concrete corrodes, it dissolves in the pore water to give up electron:

$$
2 \mathrm{Fe}_{(\mathrm{s})} \rightarrow 2 \mathrm{Fe}^{2+}{ }_{(\mathrm{aq})}+4 \mathrm{e}^{-}
$$

Other reactions also occur for ferrous hydroxide $\left(\mathrm{Fe}(\mathrm{OH})_{2}\right)$, ferric hydroxide $\left(\mathrm{Fe}(\mathrm{OH})_{3}\right)$ and finally hydrated ferric oxide $\left(\mathrm{Fe}_{2} \mathrm{O}_{3} \cdot \mathrm{H}_{2} \mathrm{O}\right)$, usually called "rust", to form. These reactions are expressed as follows:

$$
\begin{gathered}
\mathrm{Fe}^{2+}+2(\mathrm{OH})^{-} \rightarrow \mathrm{Fe}(\mathrm{OH})_{2} \\
4 \mathrm{Fe}(\mathrm{OH})_{2}+\mathrm{O}_{2}+2 \mathrm{H}_{2} \mathrm{O} \rightarrow 4 \mathrm{Fe}(\mathrm{OH})_{3} \\
2 \mathrm{Fe}(\mathrm{OH})_{3} \rightarrow \mathrm{Fe}_{2} \mathrm{O}_{3} \cdot \mathrm{H}_{2} \mathrm{O}+2 \mathrm{H}_{2} \mathrm{O}
\end{gathered}
$$

The full corrosion process will generate the unhydrated ferric oxide $\left(\mathrm{Fe}_{2} \mathrm{O}_{3}\right)$, which has a volume 
of about twice that of the reinforcement it replaces. When it becomes hydrated, it swells even more and becomes porous. The volume increase at the reinforcement and concrete interface is $2 \sim 10$ times [1]. This leads to the cracking and spalling of concrete cover observed as the usual consequence of the reinforcement corrosion in reinforced concrete structures.

\subsubsection{Cathode Area-Reduction Process}

In the corrosion mechanisms, in contrast to oxidation process, there is a simultaneous reaction called reduction process occurring at cathode area to consume the electrons. Electrons created at the anode area under oxidation process must be consumed elsewhere on the reinforcement surface to preserve electrical neutrality. In reduction reaction, oxygen and water must be available for the corrosion reaction to proceed:

$$
2 \mathrm{H}_{2} \mathrm{O}+\mathrm{O}_{2}+4 \mathrm{e}^{-} \rightarrow 4(\mathrm{OH})^{-}
$$

\section{Steel Reinforcement Corrosion Models}

\subsection{Service Life and Limit States}

Service life is the period of time during which the structure is capable of carrying out its intended function at a satisfactory performance level with routine maintenance incorporated. The service life of structural components can be treated differently. The necessary actions taken at the end of service life for bridge structural components or materials may include replacement or major repair of those components or materials.

Limit states of concrete durability usually refer to the minimum acceptable state of performance or maximum acceptable state of degradation throughout its service life. The limit states may be set with regard to the ultimate limit or the serviceability limit. Usually, limit states considered for concrete structures due to reinforcement corrosion include corrosion initiation, concrete cracking, spalling and delamination of the concrete cover, and ultimately structural failure. The change of the state of corrosion of reinforcing steel in concrete can be expressed as a function of time. The prediction of service life of corrosion-damaged concrete structures differs from the adopted limit states. Two limit states are identified by Sarja and Vesikari [2] with regard to the service life as shown in Fig. 1:

- Limit State 1: The service life ends when the protective thin film is depassivated. The process of depassivation takes an initiation period $\left(t_{0}\right)$, which is the time from construction to the time of initiation of corrosion. Thus, the following formula for service life can be used:

$$
t_{L}=t_{0}
$$

where:

$$
\begin{aligned}
& t_{L}=\text { the service life; } \\
& t_{0}=\text { the initiation time of corrosion; }
\end{aligned}
$$

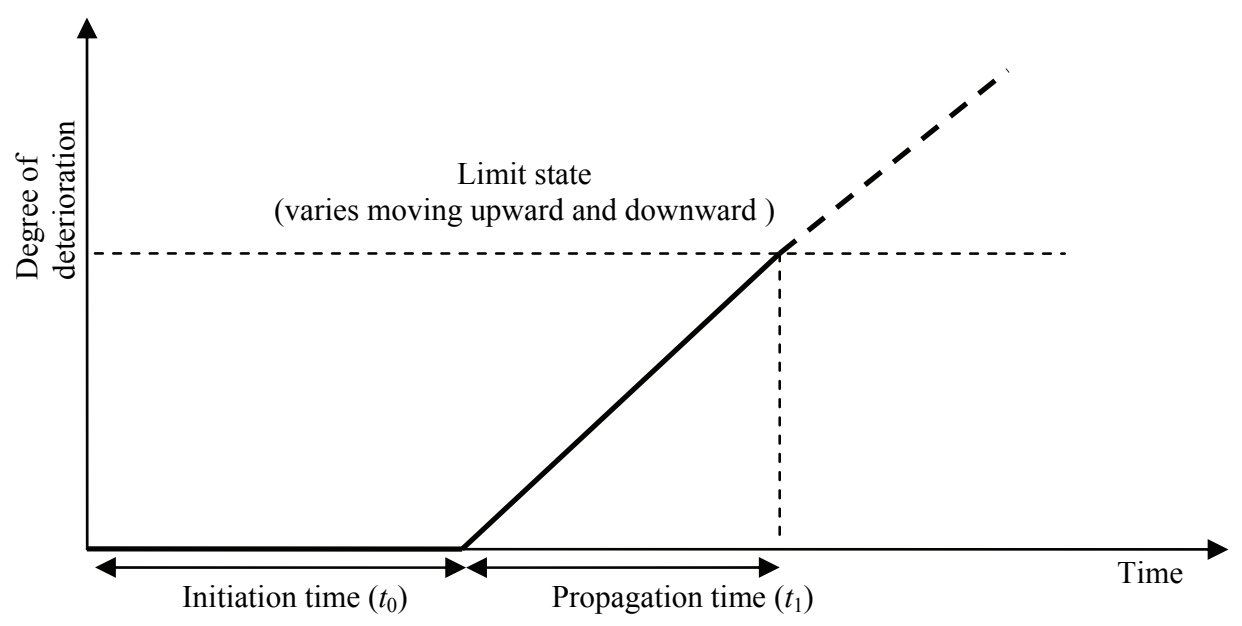

Fig. 1 Determination of service life with respect to corrosion of reinforcement [2]. 
- Limit State 2: This limit state is based on the cracking of the concrete cover due to oxides generated during corrosion. In this case, the service life includes a certain propagation period in which the cross-sectional area of reinforcement is progressively decreased, the bond between reinforcement and concrete reduced and the effective cross-sectional area of concrete diminished due to spalling of the concrete cover. During the propagation period, the reinforcement corrosion is schematically assumed to be in a steady state as indicated by a straight line in Fig. 1.

The service life based on cracking of the concrete cover is defined as the sum of initiation time of corrosion and the time for cracking of the concrete cover to a given limit:

$$
t_{L}=t_{0}+t_{1}
$$

where:

$t_{L}=$ the service life;

$t_{0}=$ the initiation time of corrosion;

$t_{1}=$ the propagation time of corrosion.

\subsection{Initiation Time $\left(t_{0}\right)$-Carbonation Induced} Corrosion

Immediately after exposure of concrete to air, the concrete paste begins to form carbonates. These carbonates reduce the $\mathrm{pH}$ of the concrete and may damage the protective oxide film bound around the reinforcing steels. If the carbonates are found in conjunction with moisture and oxygen, the reinforcing steel may corrode. The rate of carbonation is a function of the concrete quality, the relative humidity and the concentration of carbon dioxide [3]. The penetration in time of carbonation can be described in the following formula [1]:

$$
d=K_{c} t_{0}^{1 / 2}
$$

where:

$$
\begin{aligned}
& d=\text { the depth of carbonation }(\mathrm{mm}) \text { at time } t ; \\
& K_{c}=\text { the carbonation coefficient }\left(\mathrm{mm} / \mathrm{yr}^{1 / 2}\right) ; \\
& t_{0}=\text { time }(\mathrm{yr}) .
\end{aligned}
$$

The initiation time of corrosion $t_{0}$ can be rewritten and determined according to the formula as follows:

$$
t_{0}=\left(\frac{d}{K_{c}}\right)^{2}
$$

The carbonation coefficient $K_{c}\left(\mathrm{~mm} / \mathrm{yr}^{1 / 2}\right)$ depends on a number of factors such as concrete strength, binding agents, cement content, relative humidity and temperature. Based on experimental data, the parameter $K_{c}$ has values around 1.0 1.5 $\left(\mathrm{mm} / \mathrm{yr}^{1 / 2}\right)$ for dense concrete, but can increase to $7.0 \sim 8.0\left(\mathrm{~mm} / \mathrm{yrs}^{1 / 2}\right)$ for low quality concrete and industrial environment conditions [4].

To relate more precisely with the humidity, Parrott [5] suggested that the depth of carbonation be determined on the basis of the oxygen permeability of concrete:

$$
d=\frac{64 K^{0.4} t_{0}^{n}}{c^{0.5}}
$$

where:

$d=$ the depth of carbonation (concrete cover thickness);

$K=$ the oxygen permeability of concrete at $60 \%$ relative humidity;

$t_{0}=$ time;

$c=$ alkaline $(\mathrm{CaO})$ content in the concrete cover;

$n=$ power exponent which is usually about 0.5 but decreases as the relative humidity increase above $70 \%$.

\subsection{Initiation $\left(t_{0}\right)$-Chloride Attack Induced Corrosion}

Chloride-induced corrosion is identified as the main cause of deterioration of concrete bridge structures [6]. The common sources of chlorides are seawater and deicing salts. Chloride penetration from the environment produces a profile in the concrete characterized by high chloride content near the external surface and decreasing contents at greater depths. The experience on both marine structures and bridge structures exposed to deicing salts or seawater spray has shown that in general, these profiles can be approximately modeled one-dimensionally by Fick's 
second law:

$$
\frac{\partial C}{\partial t}=D \frac{\partial^{2} C}{\partial x^{2}}
$$

where:

$C$ is the concentration of the diffusing substance at a distance $x$ from the surface at time $t$;

$D$ is the diffusion coefficient of the process.

It is a non-stationary diffusion process. The equation is usually integrated under the assumptions that: (1) The concentration of the diffusing ion, measured on the surface of the concrete, is a constant in time and is equal to $C_{0}\left(C=C_{0}\right.$ for $x=0$ and for any $y)$; (2) The coefficient of diffusion $D$ does not vary in time; (3) The concrete is homogeneous so that $D$ does not vary with the change of the thickness of the concrete; (4) The concrete does not initially contain chlorides ( $C=0$ for $x>0$ and $t=0)$. The solution [7] thus obtained is:

$$
C(x, t)=C_{0}\left[1-\operatorname{erf}\left(\frac{x}{2 \sqrt{t D}}\right)\right]
$$

where:

$C(x, t)=$ the chloride content at a distance $x$ from the concrete surface at time $t$;

$C_{0}=$ surface chloride content $(\%$ by mass of cement or concrete);

$$
\begin{aligned}
& t=\text { time; } \\
& \text { erf = error function. }
\end{aligned}
$$

The diffusion coefficient and the surface chloride content are calculated by fitting the experimental data and are often used to describe chloride profiles measured on real structures. By replacing the parameter to the cover thickness $(c)$ of the concrete structure, the initiation time for corrosion $t_{0}$ is obtained from the following formula:

$$
C_{t h}=C_{0}\left[1-\operatorname{erf}\left(\frac{c}{2 \sqrt{t_{0} D}}\right)\right]
$$

where, $C_{t h}=$ the threshold chloride content $(\%$ by mass of cement or concrete).

This formula can be simplified by using a parabola function and rewritten in the following form for the corrosion initiation time of $t_{0}$ [2]:

$$
t_{0}=\frac{1}{12 D}\left(\frac{c}{1-\left(C_{t h} / C_{0}\right)^{1 / 2}}\right)^{2}
$$

Many standards require threshold value not higher than $0.4 \%$ of chloride by weight of cement for reinforced concrete and $0.2 \%$ for prestressed concrete. This corresponds approximately to $0.05 \sim 0.07$ by weight of concrete $(0.025 \sim 0.035$ for prestressed concrete). For example, the European standard BS EN 206 [8] restricts chloride contents to $0.2 \% \sim 0.4 \%$ by mass of cement for reinforced concrete and $0.1 \% \sim 0.2 \%$ for prestressed concrete [9]. In British Standard BS 8110 [10], the maximum allowed chloride contents are $0.2 \% \sim 0.4 \%$ chloride ions by mass of cement for reinforced concrete and $0.1 \%$ for prestressed and heat-cured concrete.

Concerning values of $C_{0}$, field experience has shown this quantity to be time dependent at early ages but to tend toward a maximum after a number of years. Typical surface chloride concentrations for bridge structures were recommended by Magnat and Elgarf [4] in Table 1.

In general, the value of the diffusion coefficient for a particular concrete is considered as the rate determining parameter. The coefficient of diffusion $D$ is roughly in the order of $10^{-7} \sim 10^{-8} \mathrm{~cm}^{2} / \mathrm{s}$ [2]. The value is often calculated by fitting the experimental data to equation. Eq. (14) suggests that the lower the diffusion coefficient, the higher the resistance to chloride penetration.

\subsection{Corrosion Induced Propagation Time $\left(t_{1}\right)$}

The propagation time is the time from corrosion initiation until a specified level of corrosion induced damage state is attained. Corrosion begins when the protective thin film is destroyed as a result of falling

Table 1 Typical surface chloride concentrations [4].

\begin{tabular}{lll}
\hline Structure & Environment & $C_{0}(\%)$ \\
\hline Bridge deck & Air zone & 1.6 \\
Bridge column & Splash zone & 2.5 \\
Bridge column & Tidal zone & 5.0 \\
Bridge deck & Deicing salt & 1.6 \\
Bridge column & Deicing salt & 5.0 \\
\hline
\end{tabular}


$\mathrm{pH}$ due to carbonation or as a result of the chloride content rising above the critical value at the surface of embedded steel reinforcement. The volume expansion causes tensile stress in concrete around the reinforcing steel bar leading to cracking or spalling of the concrete cover [2]. Three main conditions occur when corrosion develops which are: (1) the reduction of cross section areas of reinforcing steel; (2) the reduction of bonding between reinforcement bar and concrete; (3) the cracking of concrete cover resulting in reduction of cross section areas for concrete load-bearing. In the case of generalized corrosion, the critical loss of rebar radius is based on the cracking of the cover. The propagation time leading to cracking is approximated by the following empirical equation suggested by Siemes et al. [11]:

$$
t_{1}=80 \frac{c}{D r}
$$

where:

$c=$ the thickness of concrete cover (mm);

$D=$ the diameter of the rebar (mm);

$r=$ the rate of corrosion in concrete $(\mu \mathrm{m} / \mathrm{yr})$.

The rate of corrosion of reinforcement is expressed by Roberts and Middleton [12] as:

$$
r=m \lambda i_{\text {corr }}
$$

where:

$m=$ corrosion coefficient dependent on type of corrosion;

$\lambda=0.0115$ which is the factor to convert the corrosion rate from $\mu \mathrm{m} / \mathrm{cm}^{2}$ to $\mathrm{mm} / \mathrm{yr}$;

$i_{c o r r}=$ corrosion current density $\left(\mu \mathrm{A} / \mathrm{cm}^{2}\right)$.

Uniform corrosion is commonly assumed when calculating levels of corrosion in reinforced concrete structures. A value of $m=2$ for the corrosion coefficient is used in Eq. (16). For pitting corrosion, the value of $m$ is typically 4 to 8 .

\section{Probabilistic Approach in Service Life Prediction}

\subsection{Determine Initiation Time $\left(t_{0}\right)$ of Chloride Induced} Corrosion

The corrosion initiation time is dependent on four random variables: concrete cover thickness, diffusion coefficient, threshold chloride content and surface chloride content (i.e., $c, D, C_{t h}$ and $C_{0}$ ). The main descriptors of these random variables can vary considerably for different highway bridge structures. Parametric studies were performed varying the expected (mean) values and coefficients of variations (C.O.V.) using a range of values based on those found in corrosion related literatures as shown in Table 2.

\subsection{Monte Carlo Simulation of Chloride-Induced Corrosion Initiation Time}

The probabilistic model for corrosion is assumed that each aforesaid random variable has a lognormal distribution. A general purpose Monte Carlo Simulation

\begin{tabular}{|c|c|c|c|c|c|}
\hline Parameters & $\begin{array}{l}\text { Major affecting } \\
\text { factors }\end{array}$ & Mean & C.O.V. & Distribution & Remarks \\
\hline $\begin{array}{l}\text { Surface chloride } \\
\text { content }\left(C_{0}\right)\end{array}$ & Environment & $\begin{array}{l}\text { Splash zone } \\
1.44 \text { weight } \% \text { of concrete } \\
\text { Tidal zone } \\
1.56 \text { weight } \% \text { of concrete }\end{array}$ & -0.7 & LN & Val [13] and Leung and Lai [14] \\
\hline $\begin{array}{l}\text { Diffusion } \\
\text { coefficient }(D)\end{array}$ & Concrete quality & $\begin{array}{l}\text { Splash zone } \\
D=10.32 \times 10^{-13} \mathrm{~m}^{2} / \mathrm{s} \\
\text { Tidal Zone } \\
D=9.34 \times 10^{-13} \mathrm{~m}^{2} / \mathrm{s}\end{array}$ & $-0.10^{*}$ & LN & Leung and Lai [14] \\
\hline $\begin{array}{l}\text { Threshold chloride } \\
\text { content }\left(C_{t h}\right)\end{array}$ & Steel quality & $0.033 \mathrm{wt} \%$ of concrete & $0.10^{*}$ & LN & Bhaskaran et al. [15] \\
\hline $\begin{array}{l}\text { Concrete cover } \\
\text { thickness }(c)\end{array}$ & Workmanship & $7.62 \mathrm{~cm}(0.0762 \mathrm{~m})$ & $0.20 *$ & LN & Enright and Frangopol [16] \\
\hline
\end{tabular}

Table 2 Parameters used for the illustrative example.

*Value indicates baseline values used for parametric studies by Enright and Frangopol [16];

LN-lognormal distribution. 


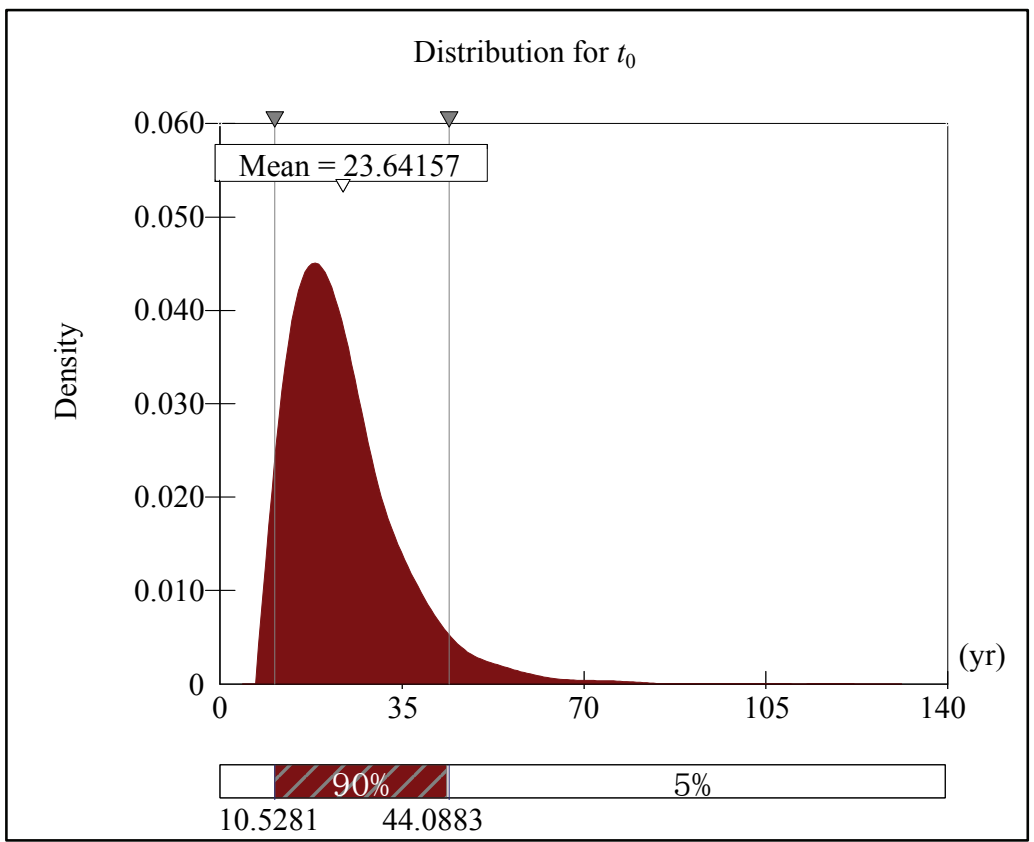

Fig. 2 Predicted initiation time of corrosion in splash zone.

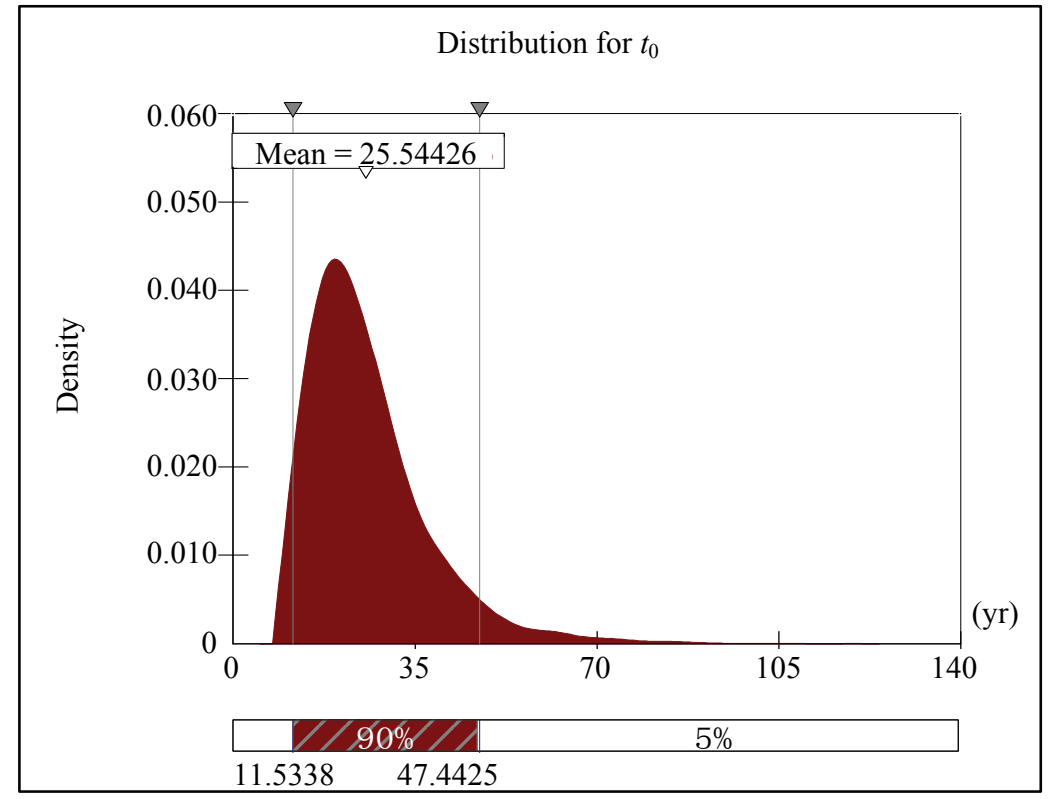

Fig. 3 Predicted initiation time of corrosion in tidal zone.

Table 3 Predicted $t_{0}$ at different locations.

\begin{tabular}{lll}
\hline \multirow{2}{*}{ Predicted $t_{0}$} & \multicolumn{2}{c}{ Bridge pier } \\
\cline { 2 - 3 } & Splash zone & Tidal zone \\
\hline Mean $(\mathrm{yr})$ & 24 & 26 \\
80 percentile $(\mathrm{yr})$ & 31 & 33 \\
\hline
\end{tabular}

program-@Risk, is used to determine the main descriptors (mean and coefficient of variation) for $t_{0}$ and also the distribution of $t_{0}$. Plots of the distribution of the corrosion initiation are shown in Figs. 2 and 3.
Values as shown in Table 3 for the main descriptors of the corrosion initiation time were obtained using Monte Carlo Simulation with a sample iteration of 10,000 .

\subsection{Determine Chloride Attack Induced Corrosion Crack Propagation Time $\left(t_{1}\right)$}

The propagation period is defined as the time from the onset of corrosion until a critical damage level or 
"limit state" is reached. These limit states include the serviceability (excessive cracking, delamination, spalling, excessive deformation, and ultimate limit states (e.g., flexural failure, shear failure and punching shear failure) [17]. Corrosion of reinforcement starts when the chloride concentration at the level of reinforcement reaches threshold chloride content. After the initiation, the corrosion rate is estimated in terms of a corrosion current density $\left(i_{\text {corr }}\right)$, which is estimated and rewritten as follows [18]:

$$
i_{\text {corr }}=\frac{0.378(1-w / c)^{-1.64}}{C} \times 100
$$

where:

$w / c=$ water/cement ratio;

$C=$ the concrete cover thickness (mm);

$i_{\text {corr }}=$ corrosion current density $\left(\mu \mathrm{A} / \mathrm{cm}^{2}\right)$.

Major factors affecting the corrosion rate are the concrete quality (mainly dependent on water/cement ratio) and cover thickness. Generally, it is also assumed that corrosion will lead to a uniform reduction in the bar diameter of the reinforcing steel. In this case, the corrosion current density can be directly transformed into the loss of reinforcement by use of the Faradays' law of electrochemical equivalence, which indicates that $i_{\text {corr }}=1 \mu \mathrm{A} / \mathrm{cm}^{2}$ corresponds to a uniform corrosion penetration of $11.6 \mu \mathrm{m} / \mathrm{yr}$ [19]. It is adopted that the mean of $i_{\text {corr }}$ for medium corrosion density and its coefficient of variation of the model are 1.0 and 0.2 , respectively, and that the model follows a normal distribution [13].

The propagation time leading to cracking occurred can be approximated by combination of Eqs. (15) and (17) into:

$$
t_{1}=80 \frac{c}{D m \lambda i_{\text {corr }} \times 1,000}
$$

where:

$c=$ the cover thickness ( $\mathrm{mm})$;

$D=$ the diameter of the rebar $(\mathrm{mm})$;

$M=2$ for uniform corrosion;

$\lambda=0.0115$ which is the factor to convert the corrosion rate from $\mu \mathrm{m} / \mathrm{cm}^{2}$ to $\mathrm{mm} / \mathrm{yr}$;

$i_{\text {corr }}=$ corrosion current density $\left(\mu \mathrm{m} / \mathrm{cm}^{2}\right)$;

$t_{1}=$ propagation time period $(\mathrm{yr})$.

The probabilistic model for crack propagation is assumed that each aforesaid random variable has a lognormal distribution. Parameters as listed in Table 4 are used to simulate the distribution of $t_{1}$. A plot of the distribution of the crack propagation is shown in Fig. 4. Mean value and 80 percentile values are adopted and their corresponding values, 8.3 years and 10 years, respectively for the crack propagation time, were obtained by using Monte Carlo Simulation with a sample iteration of 10,000 .

5.4 Determine Service Life-Setting Limit State $2\left(t_{L}=\right.$ $\left.t_{0}+t_{1}\right)$

In current practice, concrete repair works will take place when concrete cracks are observed. Usually, the tolerable crack width is commonly limited to $3 \mathrm{~mm}$ for concrete bridge structures [9]. The carbon reinforcement rebar is the most commonly used as reinforcement material because of its low cost in construction. To predict the concrete repair time properly, the combination of Eqs. (14) and (18) is used to calculate the service life with regard to corrosion of the reinforcement by chloride attack. Plots

\begin{tabular}{|c|c|c|c|c|c|}
\hline Parameters & Major affecting factors & Mean & C.O.V. & Distribution & Remarks \\
\hline Cover thickness $(c)$ & Workmanship & $7.62 \mathrm{~cm}(76.2 \mathrm{~mm})$ & $0.20^{*}$ & $\mathrm{LN}$ & Enright and Frangopol [16] \\
\hline Diameter of rebar $(D)$ & Fabrication equipment & $25 \mathrm{~mm}$ & 0.02 & LN & Enright and Frangopol [16] \\
\hline Water-to-cement ratio $(w / c)$ & Workmanship & 0.45 & - & - & - \\
\hline $\begin{array}{l}\text { Rate of corrosion in } \\
\text { concrete }(r)\end{array}$ & $\begin{array}{l}\text { Ambient condition, relative } \\
\text { humidity and temperature }\end{array}$ & \multicolumn{4}{|c|}{ Step 1: obtain $i_{\text {corr }}$ by Eq. (17) and substitute into Eq. (16) } \\
\hline
\end{tabular}

Table 4 Parameters used for crack propagation.

*Value indicates baseline values used for parametric studies by Enright and Frangopol [16];

LN-lognormal distribution. 


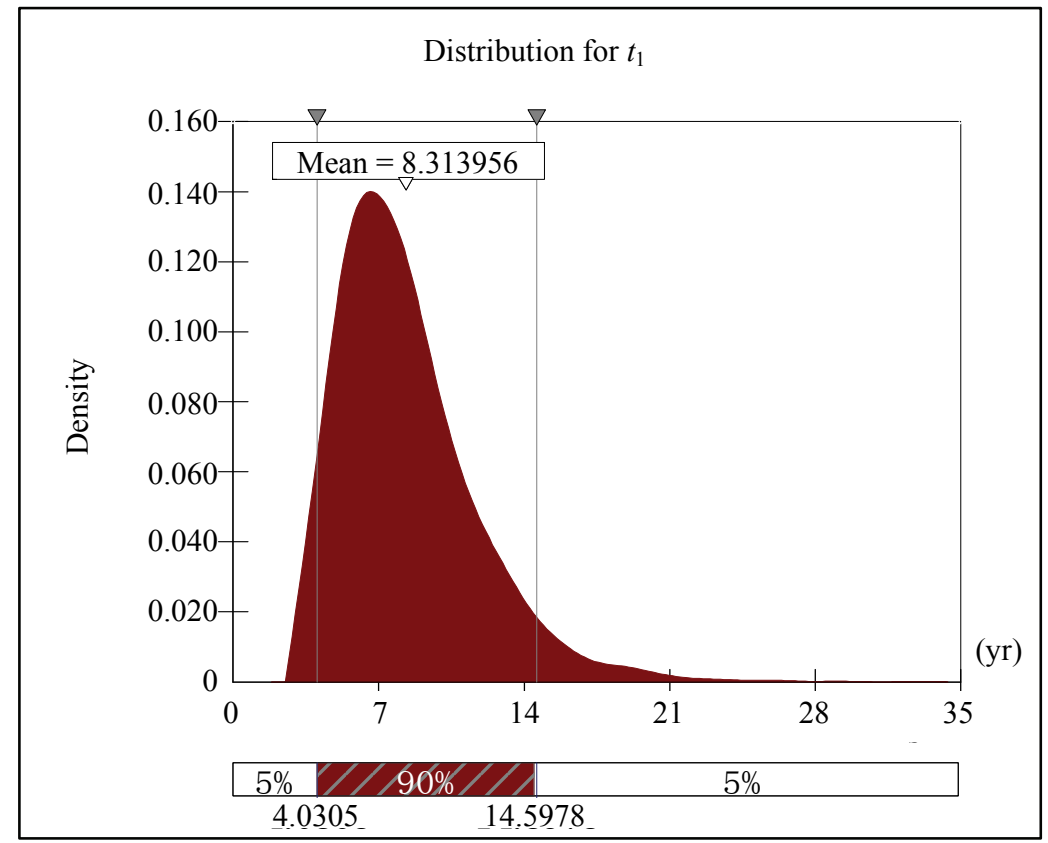

Fig. 4 Predicted propagation time of chloride attack corrosion induced cracks.

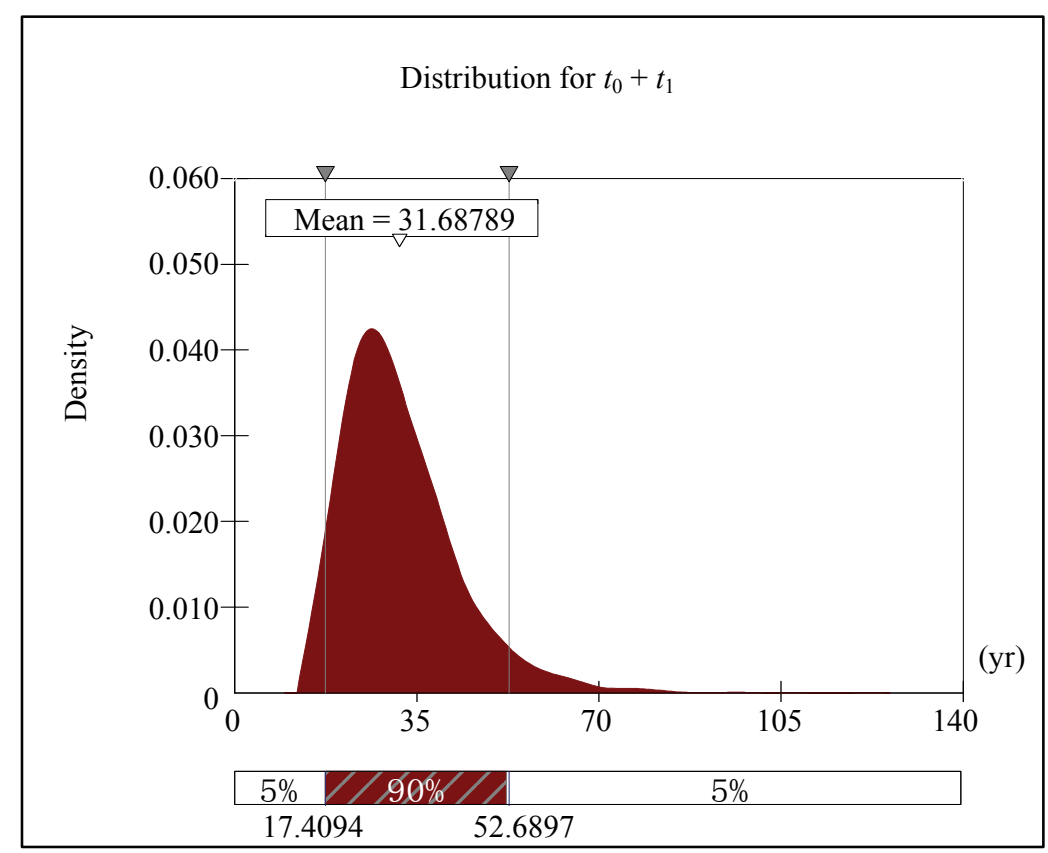

Fig. 5 Predicted $t_{0}+t_{1}$ at splash zone of bridge pier.

of simulated results are shown in Figs. 5 and 6 while the mean and the 80 percentile values are summarized in Table 5.

\section{Life-Cycle Maintenance and Repair Strategy}

Each infrastructure has to be regularly assessed and evaluated in terms of its performance, deterioration mechanism and field conditions. Then, the performance limit states are mapped with field inspection data and field condition index to come up with cost-effective maintenance and renovation strategies. In the LC (life-cycle) analysis, condition index and different repair actions should be decided by the owners based on their long-term infrastructure management plan. A sample condition index and repair 


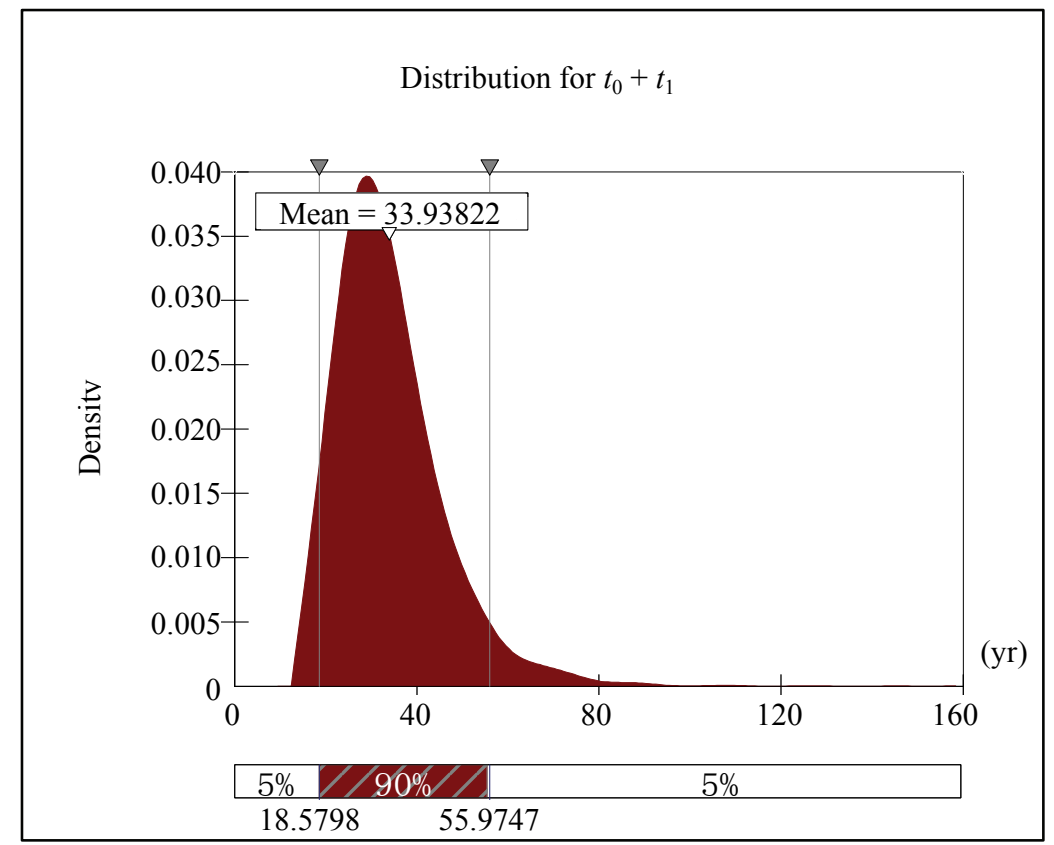

Fig. 6 Predicted $t_{0}+t_{1}$ at tidal zone of bridge pier.

Table 5 Predicted service life at splash and tidal zones of bridge pier.

\begin{tabular}{lll}
\hline \multirow{2}{*}{ Predicted $t_{0}+t_{1}$} & \multicolumn{2}{c}{ Bridge pier } \\
\cline { 2 - 3 } & Splash zone & Tidal zone \\
\hline Mean $(\mathrm{yr})$ & 32 & 34 \\
80 percentile $(\mathrm{yr})$ & 39 & 42 \\
\hline
\end{tabular}

action sets are shown in Tables 6 and 7. In addition, the changes of condition index corresponding to different repair actions are illustrated in Table 8.

The major concrete deterioration happened in tropical region like Hong Kong is attributed to the chloride attack to the splash zone and the tidal zone of bridge supporting structures particularly to those located at coastal areas. To obtain an optimized maintenance strategy for concrete structures, a systematic repair or rehabilitation decision making process should be established at the first place.

In practice, the carbon steel rebar is still the most commonly used reinforcement material other than epoxy coated or stainless steel because of its low cost in construction. However, carbon steel rebar reinforced concrete structures require more frequent repair and maintenance actions throughout its whole life cycle in order to maintain an acceptable service level. Appropriate repair methods and its timing are the key for the life-cycle analysis. Different repair time of a conventional carbon steel reinforced concrete pier at splash zone is used as an illustrative example for the life-cycle maintenance strategy comparison as shown in Tables 9 and 10:

- Case 1 represents repair action Code No. 6 taken place at the simulated corrosion initiation time $t_{0}$. The aim of the repair action for Case 1 is to reduce the chloride content of the concrete so that the time to initiate steel reinforcement corrosion can be extended;

- Case 2 represents repair action Code No. 10 taken place at the sum of simulated initiation and propagation time $t_{0}+t_{1}$. The aim of the repair action for Case 2 is to completely remove defective concrete, thoroughly clean corroded reinforcements and patch new concrete on the affected areas;

- Case 3 represents repair action Code No. 2 taken place at the corrosion initiation time $t_{0}$. The aim of the repair action for Case 3 is to reduce the rate of chloride ingress by using hydrophobic pore liners to reduce the permeability of concrete surface so that the time to initiate steel reinforcement corrosion can be extended. However, the extension period by Code No. 2 is shorter than that of Code No. 6. 
Table 6 Proposed condition index for reinforced concrete supporting structures.

\begin{tabular}{lllll}
\hline Defect code & $\begin{array}{l}\text { Defect categories } \\
\text { by field inspection }\end{array}$ & Generalized defect description & $\begin{array}{l}\text { Proposed CI } \\
\text { condition index) }\end{array}$ & $\begin{array}{l}\text { Discrete state }\left(\Omega^{\prime}\right) \\
\text { description }\end{array}$ \\
\hline 1 & Hairline crack $<0.3 \mathrm{~mm}$ & No significant defect & $0.8 \sim 1.0$ & $\begin{array}{l}\text { Good } \\
\text { (keep observation) }\end{array}$ \\
\hline 2 & Concrete cracks $<1 \mathrm{~mm}$ & Minor defect of non-urgent nature $0.6 \sim 0.8$ & $\begin{array}{l}\text { Satisfactory } \\
\text { (repair not urgent, and keep } \\
\text { observation) }\end{array}$ \\
\hline 3 & $\begin{array}{l}\text { Concrete crack 1 3 mm, map } \\
\text { cracking, coating blister, } \\
\text { dripping, ponding, } \\
\text { honeycombing, damp patch }\end{array}$ & $\begin{array}{l}\text { Defects of an unacceptable nature } \\
\text { which should be included for } \\
\text { attention in the next year }\end{array}$ & $0.4 \sim 0.6$ & $\begin{array}{l}\text { Fair } \\
\text { (minor repair required) }\end{array}$ \\
\hline $\begin{array}{l}\text { Concrete crack } 3 \sim 6 \mathrm{~mm}, \\
\text { rusting stain (few), } \\
\text { efflorescence, delamination, } \\
\text { spalling (rebar not exposed) }\end{array}$ & $\begin{array}{l}\text { Defects of an unacceptable nature } \\
\text { which should be included for } \\
\text { attention as fairly urgent }\end{array}$ & $0.2 \sim 0.4$ & $\begin{array}{l}\text { Poor } \\
\text { (fairly urgent major repair } \\
\text { required) }\end{array}$ \\
\hline $\begin{array}{l}\text { Concrete broken off, rusting } \\
\text { stain (numerous), spalling } \\
\text { to/behind rebars, concrete } \\
\text { crack }>6 \text { mm }\end{array}$ & $\begin{array}{l}\text { Severe defects which require } \\
\text { urgent/immediate action }\end{array}$ & $0 \sim 0.2$ & $\begin{array}{l}\text { Failure (urgent/immediate } \\
\text { major repair required) }\end{array}$ \\
\hline
\end{tabular}

Table 7 Proposed repair action set of defective concrete due to chloride attack.

\begin{tabular}{|c|c|c|c|}
\hline Action description & Action matrix & Repair code & Specific repair code description \\
\hline Do nothing & $\mathrm{a}_{1}$ & 0 & Observation \\
\hline \multirow{6}{*}{ Reduce corrosion rate } & \multirow{6}{*}{$a_{2}$} & 1 & $\begin{array}{l}\text { Coating and sealants } \\
\text { (acrylics, rubber, copolymers, epoxy resin and polyurethanes) }\end{array}$ \\
\hline & & 2 & Hydrophobic pore liners (silicones, siloxane and silanes) \\
\hline & & 3 & Pore blockers (silicates and silicofluorides) \\
\hline & & 4 & Rendering (plain or polymer-modified cement mortars) \\
\hline & & 5 & Complete encapsulation \\
\hline & & 6 & Desalination \\
\hline \multirow{2}{*}{ Repair visual defects (cracks) } & \multirow{2}{*}{$a_{3}$} & 7 & $\begin{array}{l}\text { Cleaning by vacuum suction and sealed by } \\
\text { injection with the use of pressure grouting method }\end{array}$ \\
\hline & & 8 & $\begin{array}{l}\text { Cleaning by water jetting and filled up by } \\
\text { polymer modified cementitious mortars }\end{array}$ \\
\hline \multirow{2}{*}{$\begin{array}{l}\text { Carry out major repairs } \\
\text { (delamination or spalling) }\end{array}$} & \multirow{2}{*}{$\mathrm{a}_{4}$} & 9 & Patching and surface sheeting \\
\hline & & 10 & Patching and surface painting \\
\hline Apply cathodic protection & $\mathrm{a}_{5}$ & 11 & Patching and cathodic protection \\
\hline Replace affected elements & $\mathrm{a}_{6}$ & 12 & Closure of structures and replacement of affected elements \\
\hline
\end{tabular}

Evaluation results as shown in Table 10 demonstrates that Case 3-concrete repair action by using method Code No. 2 taken place at corrosion initiation time, will achieve the lowest life-cycle cost compared with other cases. In comparison, Case 1 - concrete repair action by using method Code No. 10 taken place at the same repair time costs slightly higher than Case 3 . However, one repair act can be saved throughout the whole service life because the repair action in Case 1 can attribute to a longer service life extension. Case 2 reflects the conventional deterministic repair strategy-action costs the highest when cracks are observed.

\section{Conclusions}

Reinforced concrete is widely used in modern infrastructure development. Corrosion is a commonly encountered cause of deterioration in many concrete structures. Deterioration of public infrastructure presents great financial, safety, technical and operational challenges to government organizations in charge of public infrastructure development and management. To facilitate efficient and effective infrastructure facilities management, this paper has 
Table 8 Condition index after corresponding repair action.

\begin{tabular}{|c|c|c|}
\hline Initial condition index & Possible repair action & CI after repair action \\
\hline \multirow{6}{*}{$0.8 \sim 0.1$} & $\mathrm{a}_{1}$ & $0.8 \sim 1.0$ \\
\hline & $\mathrm{a}_{2}$ & $0.8 \sim 1.0$ \\
\hline & $\mathrm{a}_{3}$ & $0.8 \sim 1.0$ \\
\hline & $\mathrm{a}_{4}$ & $0.8 \sim 1.0$ \\
\hline & $\mathrm{a}_{5}$ & $0.8 \sim 1.0$ \\
\hline & $\mathrm{a}_{6}$ & $0.8 \sim 1.0$ \\
\hline \multirow{6}{*}{$0.6 \sim 0.8$} & $a_{1}$ & $0.6 \sim 0.8$ \\
\hline & $\mathrm{a}_{2}$ & $0.6 \sim 0.8$ \\
\hline & $\mathrm{a}_{3}$ & $0.8 \sim 1.0$ \\
\hline & $\mathrm{a}_{4}$ & $0.8 \sim 1.0$ \\
\hline & $a_{5}$ & $0.8 \sim 1.0$ \\
\hline & $\mathrm{a}_{6}$ & $0.8 \sim 1.0$ \\
\hline \multirow{6}{*}{$0.4 \sim 06$} & $\mathrm{a}_{1}$ & $0.4 \sim 0.6$ \\
\hline & $\mathrm{a}_{2}$ & $0.4 \sim 0.6$ \\
\hline & $\mathrm{a}_{3}$ & $0.6 \sim 0.8$ \\
\hline & $\mathrm{a}_{4}$ & $0.8 \sim 0.1$ \\
\hline & $a_{5}$ & $0.8 \sim 0.1$ \\
\hline & $\mathrm{a}_{6}$ & $0.8 \sim 0.1$ \\
\hline \multirow{6}{*}{$0.2 \sim 0.4$} & $\mathrm{a}_{1}$ & $0.2 \sim 0.4$ \\
\hline & $\mathrm{a}_{2}$ & $0.2 \sim 0.4$ \\
\hline & $\mathrm{a}_{3}$ & $0.4 \sim 0.6$ \\
\hline & $\mathrm{a}_{4}$ & $0.8 \sim 0.1$ \\
\hline & $\mathrm{a}_{5}$ & $0.8 \sim 0.1$ \\
\hline & $\mathrm{a}_{6}$ & $0.8 \sim 0.1$ \\
\hline \multirow{6}{*}{$0.0 \sim 0.2$} & $\mathrm{a}_{1}$ & $0.0 \sim 0.2$ \\
\hline & $\mathrm{a}_{2}$ & $0.0 \sim 0.2$ \\
\hline & $a_{3}$ & $0.0 \sim 0.2$ \\
\hline & $\mathrm{a}_{4}$ & $0.2 \sim 0.4$ \\
\hline & $\mathrm{a}_{5}$ & $0.6 \sim 0.8$ \\
\hline & $\mathrm{a}_{6}$ & $0.8 \sim 1.0$ \\
\hline
\end{tabular}

Table 9 Input parameters of LCC (life-cycle cost) management analysis.

\begin{tabular}{|c|c|}
\hline Model input parameters & Data \\
\hline LCC analysis period $T^{\mathrm{a}}$ & 100 years \\
\hline Discount rate $D^{\mathrm{b}}$ & $4 \%$ \\
\hline Estimated rehabilitation/repair cost $C_{R E P}{ }^{\mathrm{c}}$ & Varies in different options \\
\hline Cost of conventional rebar ${ }^{\mathrm{d}}$ & $\mathrm{HK} \$ 4,750$ per $\mathrm{t}$ \\
\hline Cost of stainless steel rebar ${ }^{\mathrm{d}}$ & HK $\$ 39,200$ per $\mathrm{t}$ \\
\hline Cost of epoxy coated rebar ${ }^{\mathrm{d}}$ & HK $\$ 7,350$ per $\mathrm{t}$ \\
\hline Cost of concrete at Grade $45^{\mathrm{d}}$ & $\mathrm{HK} \$ 1,200 / \mathrm{m}^{3}$ \\
\hline Average construction cost per structural unit ${ }^{\mathrm{d}}$ & $\mathrm{HK} \$ 3,000 / \mathrm{m}^{2}$ \\
\hline
\end{tabular}

${ }^{a}$ Highway structures in Hong Kong are usually designed for 50 years to 100 years;

${ }^{\mathrm{b}}$ Discount rate. It is recommended to use real discount rates to reflect the true time value of money with no inflation premium. Discount rate in Hong Kong is usually below $5 \%$. Discount rate at $4 \%$ is adopted here for sample illustration only;

${ }^{c}$ Rehabilitation/repair cost covers removal of deteriorated concrete, cleaning of rebar and patching of new concrete at the grade same as the original structure;

${ }^{\mathrm{d}}$ Average construction cost per structural unit is estimated based on the rate of rebar and concrete from the bill of quantity of the current on-going highway bridge projects and quotations from major local contractors in Hong Kong as of June 2007. 
Table 10 Life-cycle cost analysis at different repair time for reinforced concrete pier at splash zone.

\begin{tabular}{|c|c|c|c|c|c|c|c|c|c|}
\hline \multirow[b]{2}{*}{ Repair action } & \multicolumn{3}{|c|}{ Case 1} & \multicolumn{3}{|c|}{ Case 2} & \multicolumn{3}{|c|}{ Case 3} \\
\hline & $\begin{array}{l}\text { Time } \\
(\mathrm{yr})\end{array}$ & $\begin{array}{l}\text { Cost } \\
\left(\mathrm{HK} \$ / \mathrm{m}^{2}\right)\end{array}$ & $\begin{array}{l}\text { NPV (net } \\
\text { present } \\
\text { value) }\end{array}$ & $\begin{array}{l}\text { Time } \\
(\mathrm{yr})\end{array}$ & $\begin{array}{l}\text { Cost } \\
\left(\mathrm{HK} \$ / \mathrm{m}^{2}\right)\end{array}$ & $\begin{array}{l}\text { NPV (net } \\
\text { present } \\
\text { value) }\end{array}$ & $\begin{array}{l}\text { Time } \\
(\mathrm{yr})\end{array}$ & $\begin{array}{l}\text { Cost } \\
\left(\mathrm{HK} \$ / \mathrm{m}^{2}\right)\end{array}$ & $\begin{array}{l}\text { NPV (net } \\
\text { present } \\
\text { value) } \\
\end{array}$ \\
\hline 1st repair & 47 & 1,500 & 237 & 39 & 2,500 & 542 & 43 & 1,000 & 185 \\
\hline 2nd repair & 63 & 1,500 & 127 & 78 & 2,500 & 117 & 55 & 1,000 & 116 \\
\hline 3rd repair & 79 & 1,500 & 68 & - & - & - & 67 & 1,000 & 72 \\
\hline 4th repair & 95 & 1,500 & 36 & - & - & - & 79 & 1,000 & 45 \\
\hline 5th repair & - & - & - & - & - & - & 91 & 1,000 & 28 \\
\hline Salvage $\mathrm{S}^{\mathrm{a}}$ & 100 & 0 & 0 & 100 & 0 & 0 & 100 & 0 & 0 \\
\hline Total NPV & \multicolumn{3}{|c|}{$\mathrm{HK} \$ 3,468 / \mathrm{m}^{2}$} & \multicolumn{3}{|c|}{$\mathrm{HK} \$ 3,659 / \mathrm{m}^{2}$} & \multicolumn{3}{|c|}{$\mathrm{HK} \$ 3,446 / \mathrm{m}^{2}$} \\
\hline $\begin{array}{l}\text { Average construction cost } \\
\text { per structural unit }\left(\mathrm{HK} \$ / \mathrm{m}^{2}\right)\end{array}$ & \multicolumn{3}{|l|}{3,000} & \multicolumn{3}{|l|}{3,000} & \multicolumn{3}{|l|}{3,000} \\
\hline $\begin{array}{l}\text { 1st repair time }(t) \text { by } \\
\text { corrosion deteriorating } \\
\text { model }^{\text {b }}\end{array}$ & \multicolumn{3}{|c|}{$\begin{array}{l}t=t_{0}=31 \mathrm{st} \text { year } \\
\text { (initiation) }\end{array}$} & \multicolumn{3}{|c|}{$\begin{array}{l}t=t_{0}+t_{1}=39 \text { th year } \\
\text { (initiation }+ \text { propagation) }\end{array}$} & \multicolumn{3}{|c|}{$\begin{array}{l}t=t_{0}=31 \text { st year } \\
\text { (initiation) }\end{array}$} \\
\hline Percentile $^{b}$ & \multicolumn{3}{|l|}{$80 \%$} & \multicolumn{3}{|l|}{$80 \%$} & \multicolumn{3}{|l|}{$80 \%$} \\
\hline 1st repair action and code ${ }^{c}$ & \multicolumn{3}{|c|}{$\begin{array}{l}\text { Reduce corrosion rate, } \\
\mathrm{A}=\left\{\mathrm{a}_{2}\right\} \text { and Code } 6\end{array}$} & \multicolumn{3}{|c|}{$\begin{array}{l}\text { Carry out major repairs, } \\
\mathrm{A}=\left\{\mathrm{a}_{4}\right\} \text { and Code } 10\end{array}$} & \multicolumn{3}{|c|}{$\begin{array}{l}\text { Reduce corrosion rate, } \\
\mathrm{A}=\left\{\mathrm{a}_{2}\right\} \text { and Code } 2\end{array}$} \\
\hline $\begin{array}{l}\text { Service life } \\
\text { extension after } \\
\text { repair }^{\mathrm{d}}(\mathrm{yr}) \\
\end{array}$ & \multicolumn{3}{|c|}{ (5) } & \multicolumn{3}{|c|}{ 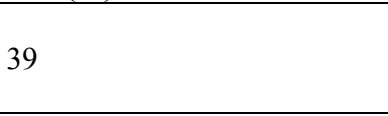 } & \multicolumn{3}{|c|}{ (25) } \\
\hline Subsequent repair methods ${ }^{\mathrm{e}}$ & \multicolumn{3}{|c|}{ Same as 1 st repair } & \multicolumn{3}{|c|}{ Same as 1 st repair } & \multicolumn{3}{|c|}{ Same as 1 st repair } \\
\hline
\end{tabular}

${ }^{\mathrm{a}}$ For simplicity, zero salvage value for all options is assumed;

${ }^{\mathrm{b}}$ Service life for each case is determined by chloride attack corrosion deteriorating model. The expected time of repair for all cases obtained by simulation (i.e., Case 1 at $t_{0}$ by Code 6 , Case 2 at $t_{0}+t_{1}$ by Code 10 and Case 3 at $t_{0}$ by Code 2) are at 80 percentile. 80 percentile for risk analysis is commonly adopted in Hong Kong for major highway projects;

${ }^{\mathrm{c}}$ Repair action and code refers to Table 7;

${ }^{\mathrm{d}}$ Extended service life and frequency of repair are based on corrosion deteriorating model and local maintenance experiences;

${ }^{\mathrm{e}}$ For simplicity, repair methods in corresponding cases are unchanged.

developed a performance-based life-cycle management model through a systematic approach. It has successfully developed the necessary linkages between various corrosion mechanisms and the field performance conditions as well as limit states so that it can be used for the development of effective life-cycle management strategies for reinforced concrete infrastructures.

A case study is provided to demonstrate the use of the proposed performance-based, life-cycle management model. The results show that the proposed model is useful and applicable to infrastructure facilities management. As the model is based on the probability, the actual comparison with field experiment requires many field performance data during the life span of an infrastructure which is very difficult to obtain. However, the corrosion deterioration models used in this paper have been well verified by laboratories and field experimental results.

Even though it is well-known that the main cause for deterioration of reinforced concrete structures is due to corrosion of reinforcement, we should be aware that the deterioration of concrete structures may also be affected by many other factors in addition to corrosion, for example, material property, load, and frequency of usage. These factors are not considered in this paper. However, it could be easily included in the life-cycle management model, if required.

\section{Acknowledgments}

The work described in this paper was financially supported by the Seed Grants for Research Scheme 
(Project Ref: 1213205) under Technological and Higher Education Institute of Hong Kong.

\section{References}

[1] Broomfield, J. P. 1997. Corrosion of Steel in Concrete-Understanding, Investigation and Repair. 1st ed. London: E\&FN SPON.

[2] Sarja, A., and Vesikari, E. 1996. Durability Design of Concrete Structures. Report of the Technical Committee 130-CSL, RILEM (International Union of Laboratories and Experts in Construction Materials, Systems and Structures).

[3] Cheung, M. S., and Kyle, B. R. 1996. "Service Life Prediction of Concrete Structures by Reliability Analysis." Construction and Building Materials 10 (1): 45-55.

[4] Mangat, P., and Elgarf, M. 1991. The Effect of Reinforcement Corrosion on the Performance of Concrete Structures. BREU P3091 report, University of Aberdeen.

[5] Parrott, P. J. 1994. "Design for Avoiding Damage Due to Carbonation-Induced Corrosion." In Durability of Concrete, edited by Malhotra, V. M. Detroit: American Concrete Institute, 293-8.

[6] Lounis, Z. 2003. "Probabilistic Modeling of Chloride Contamination and Corrosion of Concrete Bridge Structures." In Proceedings of the Fourth International Symposium on Uncertainty Modeling and Analysis, 447.

[7] Bentur, A., Diamond, S., and Berke, N. S. 1997. Steel Corrosion in Concrete-Fundamentals and Civil Engineering Practice. 1st ed. London: E\&FN SPON.

[8] British-Adopted European Standard. 2000. Concrete. Specification, Performance, Production and Conformity, BS EN 206-1:2000. UK: British-Adopted European Standard.

[9] Eibl, J., ed. 2004. Concrete Structures Euro-Design Handbook. Karlsruhe: Ernest \& Sohn.

[10] British Standard Institution. 1985. Structural Use of Concrete-Part 1: Code of Practice for Design and
Construction, BS 8110. UK: British Standard Institution.

[11] Siemes, A., Vrouwenvelder, A., and Van den Beukel, A. 1985. "Durability of Buildings: A Reliability Analysis." Heron 30 (3): 3-48.

[12] Roberts, M. B., and Middleton, C. 2000. “A Proposed Empirical Corrosion Model for Reinforced Concrete.” In Proceedings of Institution of Civil Engineers, Structures \& Buildings 140 (1): 1-11.

[13] Val, D. V. 2005. "Effect of Different Limit States on Life-Cycle Cost of RC Structures in Corrosive Environment." Journal of Infrastructure Systems 11 (4): 231-40.

[14] Leung, W. C., and Lai, T. K. 2002. "Maintenance Strategy of Reinforced Concrete Structures in Marine Environment in Hong Kong." In Proceedings of International Congress-Challenge of Concrete Construction, 277-86.

[15] Bhaskaran, B., Palaniswamy, N., and Rengaswamy, N. S. 2006. "Life-Cycle Cost Analysis of a Concrete Road Bridge Across Open Sea." Materials Performance 45 (10): 51-5.

[16] Enright, M. P., and Frangopol, D. M. 1998. "Probabilistic Analysis of Resistance Degradation of Reinforced Concrete Bridge Beams under Corrosion.” Engineering Structures 20 (11): 960-71.

[17] Lounis, Z., Martin-Perez, B., and Hunaidi, O. 2001. "Decision Support Tools for Life Prediction and Rehabilitation of Concrete Bridge Decks." Presented at APWA (American Public Works Association) International Public Works Congress, Philadelphia.

[18] Vu, K. A. T., and Stewart, M. G. 2002. "Spatial Variability of Structural Deterioration and Service Life Prediction of Reinforced Concrete Bridges." In Proceedings of 1st International Conference on Bridge Maintenance, Safety and Management, 1-10.

[19] Val, D. V., and Stewart, M. G. 2003. "Life-Cycle Cost Analysis of Reinforced Concrete Structures in Marine Environments." Structural Safety 25: 343-62. 